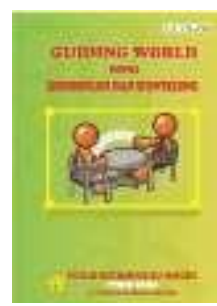

\title{
Implementasi Bimbingan Klasikal Untuk Meningkatkan Self Control Pada Peserta Didik
}

\author{
Sri Wahyuni, Faijin, Sarbudin \\ Prodi Bimbingan dan Konseling, Sekolah Tinggi Keguruan Dan Ilmu Pendidikan (STKIP) Bima \\ Email: wongfaijin@gmail.com
}

\begin{abstract}
Abstrak
Kontrol diri dapat diartikan sebagai suatu aktivitas pengendalian tingkah laku. Pengendalian tingkah laku mengandung makna yaitu, melakukan pertimbangan-pertimbangan terlebih dahulu sebelum memutuskan sesuatu untuk bertindak.Tujuan dari penelitian ini adalah untuk mengetahui:Untuk mengetahui Implementasi Bimbingan Klasikal dalam meningkatkan Self Control SMAN 3 Wera. Dalam mengumpulkan data, peneliti menggunakan metode wawancara, observasi dan dokumentasi. Sedangkan untuk analisis peneliti menggunakan analisis dekskriptif kualitatif, yaitu berupa data data tertulis, dengan tahap tahap reduksi data, Display data dan Verifikasi data.Sedangkan untuk keabshana datanya di cek menggunakan teknik tringulasi menggunakan bahan referensi dan member check. Hasil penelitian ini adalah bahwa penerapan layanan Bimbingan Klasikal dapat meningkatkan Self Control pada peserta didik yang berkaitan dengan siswa mampu mengarakan dan mengendalikan perilakunya dalam menghadapi situasi dan kondisi agar sesuai dengan orang lain, serta siswa dapat mengambil keputusan dari suatu peristiwa atau kejadian. Program bimbingan klasikal dapat mempengaruhi peningkatan prilakunya sendiri sesuai norma yang ada, Maka dari itu dengan ini peserta didik dapat mengatur setiap proses fisik, psikologis dan prilakunya, dengan kata lain serangkaian proses yang membentuk dirinya kearah yang lebih positif dan bermanfaat sesuai yang diharapkan oleh individu tersebut.
\end{abstract}

Kata Kunci : Bimbingan Klasikal, Self Control.

\section{PENDAHULUAN}

Salah satu peran guru BK dalam tugasnya sebagai pendidik adalah membimbing, yaitu membantu peserta didiknya agar berkembang mencapai kedewasaan secara optimal. Artinya kedewasaan yang sempurna (sesuai dengan kodrat yang di miliki). Guru Bimbingan dan Konseling memiliki peran yang sangat kompleks, Peran tersebut mencakup permasalahan yang terjadi di lingkungan sekolah maupun di luar lingkungan sekolah. Manfaat bimbingan dan konseling yang dilakukan oleh guru bimbingan konseling cukup penting bagi peserta didik untuk mengatasi berbagai permasalahan termasuk mengatasi permasalahan pribadi peserta didik dalam membantu meningkatkan prestasi belajar mereka.

Fenomena perilaku peserta didik dewasa ini seperti tawuran, penyalahgunaan obatobat terlarang (narkoba), perilaku seks menyimpang, degradasi moral, pencapaian hasil 


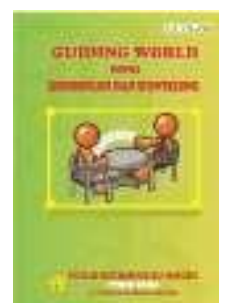

belajar yang tidak memuaskan, tidak lulus UAN, gagal ujian dan lain sebagainya menunjukan bahwa tujuan pendidikan yang salah satu upaya pencapaiannya proses pembelajaran, belum sepenuhnya mampu menjawab atau memecahkan berbagai persoalan tersebut. Guna memecahkan persoalan-persoalan tersebut, proses pendidikan dan pembelajaran perlu bersinergi dengan pelayanan bimbingan konseling. Optimalisasi layanan bimbingan konseling di sekolah perlu di lakukan, sehingga pelayanan bimbingan konseling di sekolah benar-benar memberikan kontribusi pada pencapaian visi, misi, dan tujuan sekolah.

Kepribadian peserta didik di SMA umumnya masih labil, gampang dipengaruhi oleh factor-faktor yang dapat menyeret mereka kepada hal-hal yang dapat merugikan diri mereka sendiri seperti kurangnya kesadaran mereka tentang control diri. Apabila para siswa tersebut belajar sesuai dengan kehendak sendiri dalam arti tanpa aturan yang jelas, maka upaya belajar siswa tersebut tidak dapat berjalan dengan efektif. Apalagi tantangan kehidupan sosial dewasa ini semakin kompleks, termasuk tantangan dalam mengalokasikan waktu. Dalam hal ini jika pengaturan waktu berdasarkan kesadaran sendiri maupun arahan pihak lain tidak dilakukan dengan disiplin maka semuanya akan menjadi kacau. Demikian pula dengan kedisiplinan siswa dalam melakukan aktifitas belajar dipadukan aktifitas lain dalam kehidupan sehari-hari.

Self control berkaitan dengan bagaimana individu mengendalikan emosi serta dorongan-dorongan dalam dirinya. Self control merupakan salah satu potensi yang dapat dikembangkan dan digunakan individu selama proses-proses dalam kehidupan, termasuk dalam menghadapi kondisi yang membuatnya stress (Chalhoun dan Acocella, 1995: 135). Self control dapat mencakup semua bidang perilaku, yaitu perilaku politik, sosial, spiritual, budaya, perilaku kerja, perilaku bermasyarakat, dan perilaku makan. Pengaruh self control terhadap timbulnya tingkah laku individu dapat dianggap cukup besar, karena tingkah laku overt merupakan hasil proses pengontrolan diri seorang individu.

Dalam peranan ini guru harus memperhatikan aspek-aspek pribadi setiap murid antara lain kematangan, kebutuhan, kemampuan, kecakapannya dan sebagainya agar mereka (murid) dapat mencapai tingkat perkembangan dan kedewasaan yang optimal. Seperti kita ketahui keadaan siswa-siswa SMA berlatar belakang berbeda-beda. Tidak semua siswa mempunya pengendalian diri yang sama. Karena pada dasarnya kontrol diri itu berawal dari dalam diri (internal) dan juga luar diri (eksternal) yang sifatnya berupa dorongan atau motivasi positif yang diberikan oleh orang-orang di sekitarnya. Kontrol diri dapat diartikan sebagai suatu aktivitas pengendalian tingkah laku. Pengendalian tingkah laku mengandung makna yaitu, melakukan pertimbangan-pertimbangan terlebih dahulu sebelum memutuskan sesuatu untuk bertindak.

Disinilah peran guru bimbingan dan konseling diperlukan untuk mendampingi mereka. Sehingga dengan terciptanya kedisiplinan di sekolah akan mendukung proses kegiatan belajar mengajar yang ada dan dengan proses belajar yang sesuai dengan kurikulum dan tujuan yang hendak dicapai diharapkan dapat meningkatkan prestasi belajar siswa. Pelayanan guru bimbingan dan konseling hendaknya berjalan secara efektif membantu siswa mencapai tujuan-tujuan perkembangannnya dan mengatasi permasalahannya termasuk membimbing para siswa untuk berperilaku disiplin. Kelengkapan sarana dan prasarana penunjang terus diupayakan dalam rangka mempermudah pelayanan di sekolah agar siswasiswanya yang awalnya masih mempunyai beberapa masalah yang dihadapi di sekolah misalnya tentang teman sebaya, belajar, sosial, sampai alat komunikasi atau gadget yang biasa digunakan siswa saat berada di sekolah bisa terkurangi dengan adanya dorongan atau motivasi 


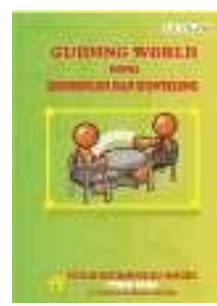

positif, guru bk serta layanan BK secara lengkap. Kondisi yang ditemukan di sekolah, masih banyak peserta didik yang mengalami masalah belajar terutama dalam pembentukan sikap belajar, susah di atur, sering membolos, tidak terlalu suka diarahkan dan cenderung membangkang. Hal ini yang menjadi dasar bagi peneliti untuk melakukan penelitian dengan judul "Implementasi Bimbingan Klasikal Untuk Meningkatkan Self Control Pada Siswa di SMA Negeri 3 Wera.

Rumusan masalah adalah bagaimana Implementasi Bimbingan Klasikal dalam Meningkatkan Self Control peserta didik, sedangkan tujuan penelitian ini adalah untuk mengetahui bagaimana Implementasi Bimbingan Klasikal dalam Meningkatkan Self Control Peserta didik di SMA Negeri 3 Wera.

\section{KERANGKA TEORITIS DAN PENGEMBANGAN HIPOTESIS}

\section{a. Bimbingan Kalasikal}

Makhrifah \& Nuryono, (2014: 1) mengemukakan bimbingan klasikal merupakan suatu layanan bimbingan dan konseling yang diberikan kepada siswa oleh guru bimbingan \& konseling (Guru BK) atau konselor kepada sejumlah siswa dalam satuan kelas yang dilaksanakan di dalam kelas. Kebutuhan dan masalah yang bersifat umum, dihadapi oleh seluruh atau sebagian besar, dan tidak selalu bersifat pribadi, dapat dibantu dengan layanan bantuan secara klasikal atau kelompok besar yang biasannya bersifat informatif, sehingga dapat segera diberikan oleh konselor atau guru BK (Sukmadinata, 2007:116\&118). Klasikal adalah format kegiatan BK yang melayani sejumlah peserta didik dalam rombongan bealajar suatu kelas (Kementerian Pendidikan Dan Kebudayaan Republik Indonesia, 2014:102). Dari penjelasan tersebut dapat dipahami bahwa bimbingan klasikal merupakan layanan yang diberikan kepada semua siswa di dalam kelas. Hal ini menunjukkan bahwa dalam proses bimbingan sudah disusun secara baik dan siap untuk diberikan kepada siswa secara terjadwal, kegiatan ini berisikan informasi yang diberikan oleh seorang pembimbing kepada siswa secara kontak langsung guna membantu pertumbuhan anak dalam menentukan dan mengarahkan hidupnya.

Layanan bimbingan dan konseling memiliki berbagai setting pelayanan, diantaranya bimbingan dalam setting klasikal dan bimbingan dalam setting kelompok. Melalui bimbingan klasikal, guru BK dapat memberikan layanan bimbingan kepada sejumlah peserta didik dengan waktu yang lebih efisien. Menurut Geltner dan Clark (2005) bimbingan klasikal adalah layanan yang bersifat pencegahan terhadap berbagai gangguan yang bisa mengancam pribadi atau kelompok (preventive),bersifat meminimalisir atau menghilangkan keburukan yang sudah terjadi(curative), bersifat memilihara hal hal positif yang dimiliki oleh individu maupun kelompok (preservative), dan bersifat mmengembangkan segala potensi yang sudah ada (developmentave)merupakan cara yang efisien dalam memberikan informasi kepada siswa sejumlah satuan kelas. Selaras dengan pendapatt Winkel dan Hastuti (2006: 561) Bimbingan klasikal adalah bimbingan yang diberikan kepada sejumlah siswa yang tergabung dalam suatu satuan kegiatan pembelajaran. Program ini mencoba mengatasi kebutuhan untuk mencegah masalah psikologis remaja dan untuk meningkatkan kematangan psikologis pada remaja. Pengertian lain menyebutkan bahwa bimbingan klasikal adalah bimbingan yang berorientasi pada kelompok siswa dalam jumlah yang cukup besar antara 30-40 orang siswa (satu kelas).

\section{Tujuan Bimbingan Klasikal}




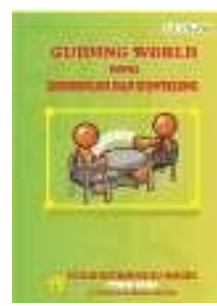

Suciati (2005) mengungkapkan bahwa bimbingan klasikal diklasifikasikan dalam beberapa tujuan sebagai berikut :

a. Tujuan bimbingan klasikal pada aspek kognitif berorientasi pada kemampuan berfikir mencakup kemampuan intelektual sederhana yakni mengingat sampai kemampuan memecahkan masalah. Secara hirarkis tujuan bimbingan klasikal pada aspek kognitif pada tingkatan paling rendah meliputi : pengetahuan, pemahaman, penerapan, analisis, sintesis dan evaluasi.

b. Tujuan bimbingan klasikal pada aspek efektif berorientasi dengan perasaan, emosi, sistem nilai dan sikap yang menunjukan penerimaan atau penolakan terhadap sesuatu.

c. Tujuan bimbingan klasikal pada aspek psikomotor berorientasi kepada keterampilan motorik yang berhubungan dengan anggota tubuh atau tindakan yang memerlukan koordinasi syaraf atau otot.

\section{Metode Bimbingan Klasikal}

Metode pelaksanaan bimbingan klasikal terdapat 9 bentuk yaitu Home Room, Diskusi Kelompok, Pelajaran Bimbingan, Kelompok Kerja, Pengajaran Perbaikan, Sosiodrama dan Psikodrama, Ceramah Bimbingan, Karya Wisata, dan Organisasi Siswa. Adapun penjelasan dari kesembilan bentuk tersebut dapat dijabarkan sebagai berikut :

\section{a) Home Room}

Merupakan teknik bimbingan klasikal yang bertujuan agar guru atau petugas bimbingan dapat mengenal siswa secara lebih mendalam, sehingga dapat membantunya secara efektif. Pengelompkan murid murid dalam home room ini dapat berdasarkan tingkatan kelas yang sama maupun merupakan gabungan dari berbagai tingkatan kelas. Jumlah siswa dapat berupa kelompok kecil, maupun kelompok besar dalam suatu kelas. Home room dilaksanakan berdasarkan suatu jadwal tertentu dalam ruangan ruangan yang telah ditentukan. Kegiatan dalam home room ini dilakukan dalam suatu situasi dan suasana yang bebas serta menyenangkan. Suasana bebas tampa adanya tekanan memungkinkan murid murid untuk melepaskan perasaannya dan mengutarakan pendapatnya yang tidak mungkin tercetus dalam pertemuan pertemuan formal.

Program home room dapat dilaksanakan secara periodik dapat pula dilaksanakan secara insidental sesuai dengan kebutuhan. Yang perlu diperhatikan dalam home room ini adalah membuat suasana kelas seperti suasana yang ada di rumah. Hubungan antara guru atau pembimbing dapat diupayakan seperti hubungan anak dan orang tua. Dengan hubungan semacam ini diharapkan para siswa secara bebas mengungkapkan isi hatinya kepada pembimbing. Pembimbing hendaknya memposisikan diri sebagai orang tua yang dengan penuh kasih sayang menampung keluhan, usul dan keinginan siswa.

b) Pelajaran Bimbingan

Teknik bimbingan klasikal ini dilakukan pada kelompok murid yang sudah dibentuk untuk keperluan pengajaran. Ini berarti bahwa bimbingan dilakukan dalam kelompok kelompok kelas yang telah ada. Dalam kegiatan ini yang lebih diutamakan adalah pada pemenuhan kebutuhan -kebutuhan siswa berkenaan dengan perkembangan pribadi dan sosialnya. Sehingga pembimbing lebih berfungsi sebagai pendidik dari pada pengajar, walaupun layanan bimbingan diberikan seperti pelajaran. Pembimbing hendaknya benar benar dapat memilih topik yang dibutuhkan siswa, sehingga semua siswa diharapkan aktif atau ada keterlibatan dari para siswa yang berdampak pada suasana kelas yang cukup bebas tapi tetap terarah. 


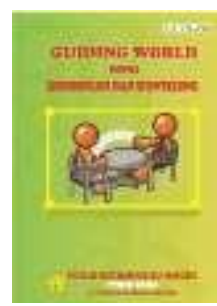

Dengan proses layanan seperti ini siswa sekedar mendapat pengetahuan namun ada perubahan dalam sikap dan tingkah laku.

\section{b. Self Control}

Self-control merupakan salah satu potensi yang dapat dikembangkan oleh setiap individu. Potensi ini dapat digunakan oleh individu selama proses kehidupan, termasuk saat menghadapi kondisi di lingkungan tempat tinggalnya. Para ahli berpendapat self-control selain dapat mereduksi efek-efek psikologis yang negatif dari stresor-stresor lingkungan, juga dapat digunakan sebagai intervensi yang bersifat pencegahan.

Menurut Rotter (dalam Wiked, 2005) kendali diri merupakan keyakinan yang berasal dari individu untuk mengendalikan perilakunya. Pendapat tersebut hampir senada dengan pandangan Mischel (dalam Pervin, 1984: 410) yang menyatakan bahwa self-control mengarah pada kekuatan individu untuk mengatur atau mengendalikan tindakannya dalam menghadapi situasi.

Sementara tokoh dalam negeri, Ghufron \& Risnawita (2010: 21) menyatakan selfcontrol merupakan suatu kecakapan individu dalam kepekaan membaca situasi diri dan lingkungannya, selain itu juga kemampuan untuk mengontrol dan mengelola perilaku sesuai dengan situasi dan kondisi agar sesuai dengan orang lain, menyenangkan orang lain, selalu konform dengan orang lain, dan menutupi perasaannya. Oktarini (2014: 11) menyatakan bahwa self-control merupakan aktivitas pengendalian tingkah laku. Menurut Messina dan Messina (dalam Ghufron \& Risnawita, 2010) pengendalian diri merupakan tingkah laku yang terfokus pada keberhasilan mengubah pribadi, menangkal self-destructive, perasaan outonomy, atau bebas dan pengaruh orang lain, kebebasan menentukan tujuan, kemampuan untuk memisahkan perasaan dan pikiran rasional dan tingkah laku yang terfokus pada tanggung jawab pribadi. Disisi lain Logue (1995: 7) memaknai kontrol diri pada pilihan tindakan yang akan memberikan manfaat serta keuntungan dengan cara menunda kepuasan sesaat. Proses pengontrolan diri ini menjelaskan bagaimana diri mengatur dan mengendalikan perilaku dalam menjalani kehidupan sesuai dengan kemampuan individu dalam mengendalikan perilaku. Apabila individu mampu mengendalikan perilakunya dengan baik maka indivisu dapat menjalani kehidupan dengan baik.

Self control memilki beberapa aspek yang harus diperhatikan. Untuk mengukur self control digunakan aspek-aspek Kemampuan mengontrol perilaku, Kemampuan mengontrol stimulus, Kemampuan mengantisipasi suatu peristiwa atau kejadian, Kemampuan menafsirkan suatu peristiwa atau kejadian, serta Kemampuan mengambil keputusan (Chalhoun dan Acocella,1995: 140). Berdasarkan beberapa uraian tentang konsep dasar self control tersebut dapat disimpulkan self control adalah suatu kemampuan yang dimiliki oleh individu dalam mengatur dan mengarahkan perilakunya berdasarkan proses koginitif dan psikologis sehingga menghasilkan perilaku yang sesuai dengan yang diharapkan individu tersebut.

Berdasarkan pendapat para ahli, maka dapat disimpulkan self-control adalah kemampuan seseorang dalam mengontrol perilaku, mengontrol pikiran dan mengontrol keputusan sesuai dengan situasi dan kondisi yang dapat membawa individu ke arah konsekuensi positif. Pengendalian diri (self-control) memiliki jenis yang beragam.

\section{Jenis jenis Self Control.}

Block dan Block (dalam Lazarus, 1976: 238) mengemukakan tiga jenis selfcontrol, yaitu: 


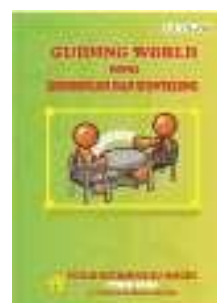

1. Over control, yaitu kontrol yang berlebihan sehingga menyebabkan sesorang banyak mengontrol dan menahan diri untuk bereaksi terhadap stimulus;

2. Appropriate control, yaitu kontrol yang memungkinkan individu mengontrol impulsnya dengan tepat;

3. Under control, yaitu kecenderungan untuk melepaskan impuls dengan bebas tanpa perhitungan yang matang.

Menurut Sarafina (dalam Muharsih, 2008: 26) self-control yang digunakan individu dalam menghadapi suatu stimulus meliputi:

1. Behavior control, yaitu kemampuan individu untuk mengambil tindakan kongkrit untuk mengurangi akibat stressor. Tindakan mengurangi stressor dapat berupa pengurangan intensitas kejadian atau memperpendek durasi kejadian;

2. Cognitive control, yaitu kemampuan individu untuk menggunakan proses berpikir atau strategi untuk memodifikasi akibat stressor. Strategi memodifikasi stressor dapat berupa penggunaan cara yang berbeda dalam memikirkan kejadian tersebut atau pada pemikiran yang menyenangkan atau netral;

3. Declaration control, kesempatan untuk memilih antara prosedur alternatif atau tindakan yang dilakukan;

4. Information control, yaitu kesempatan untuk mendapatkan pengetahuan mengenai kejadian yang menimpa remaja, kapan akan terjadi, mengapa dan apa konsekuensinya. Kontrol informasi dapat memprediksi dalam menghadapi sesuatu yang tidak diketahuinya;

5. Retrospective control, yaitu menyinggung kepercayaan mengenai apa atau siapa yang menekan setelah kejadian itu terjadi.

Menurut Logue (1995: 24) orang yang mampu Mengontrol diri adalah orang yang memiliki ciri-ciri:

1. Memegang teguh tugas yang berulang meskipun berhadapan dengan berbagai gangguan.

2. Mengubah perilakunya sendiri sesuai dengan norma yang ada.

3. Tidak menunjuk perilaku yang dipengaruhi oleh amarah.

4. Bersikap toleransi terhadap stimulus yang berlawanan.

Disisi lain Surya (2003: 51) berpendapat bahwa kendali diri mempunyai makna sebagai daya yang memberi arah bagi individu dalam hidupnya dan tanggung jawab penuh terhadap konsekuensi dari perilakunya. Semakin mampu individu mengendalikan perilakunya, maka semakin mungkin menjalani hidupnya secara efektif serta terhindar dari situasi yang dapat mengganggu perjalanan hidupnya.Individu yang kurang memiliki kendali diri disebabkan karena tidak belajar kecakapan dan pengorbanan untuk mencapai satu tujuan, dan tidak belajar bagaimana untuk menjadi dirinya sendiri.Masalah yang timbul diantaranya sebagai berikut.

1. Menunjukkan rendahnya disiplin diri.

2. Rendahnya kecakapan untuk menata diri sendiri.

3. Lebih banyak dikendalikan oleh kesadaran tidak rasional.

4. Dikendalikan oleh kekuatan pihak lain yang tidak sehat.

5. Lebih banyak dikendalikan oleh pikiran-pikiran orang lain.

6. Dikendalikan oleh kebutuhan dan perasaan yang mentah. 


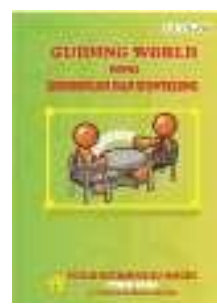

DOI: 1033627

Volume 03, Nomor 01

Mei 2020

E-ISSN: 2614-3585

\section{METODE}

Jenis penelitian yang digunakan peneliti adalah penelitian kualitatif yaitu penelitian yang menghasilkan data deskriptif berupa kata-kata tertulis atau lisan dari orang-orang dan perilaku yang diamati (Suharsini Arikunto,1993: 102). Menurut Bogdan dan Taylor penelitian kualitatif adalah prosedur penelitian yang menghasilkan data deskriptif berupa kata kata,tulisan atau lisan dari orang yang perlu diamati. Menurut mereka pendekatan ini diarahkan pada latar dan iindividual tersebut secara holistik (utuh). Penelitian kualitatif adalah suatu pendekatan yang jga disebut pendekatan investigasi karena biasanya penelitian mengumpulkan data denga cara bertatap muka langsung dan berinteraksi dengan orang orang ditempat penelitian (McMilan \& Scumacher,2003). Dengan pendekatan kualitatif ini peneliti akan menggambarkan dan menganalisa setiap individu dalam kehidupan dan pemikirannya. Sesuai pendekatan yang digunakan daalam penelitian ini yaitu pendekatan kualitatif, maka kehadiran peneliti dilapangan merupakan hal yang sangat penting karena peneliti bertindak sebagai instrument utama dan sekaligus sebagai pengumpul data penelitian yang diperlukan. Menurut Bogdan dan Biklen (dalam Moleong, 2001) menyatakan bahwa sebagai instrument kunci, peneliti harus dapat menangkap makna dan berinteraksi terhadap nilai-nilai lokal. Penelitian dilaksanakan di SMA Negeri 3 Wera dengan sumber data 1 orang konselor dan 7 orang siswa yang memiliki self control kurang. Tehnik pengumpulan data adalah wawancara, dokumentasi dan observasi. Sedangkan tehnik analisis data yang digunakan dalam metode analisis kualitatif adalah Reduksi data, Display data, Verifikasi data. Teknik pengujian keabsahan data dalam penelitian ini menggunakan teknik triangulasi.

\section{HASIL DAN PEMBAHASAN (12pt bold Styles Heading 1)}

Jumlah subyek penelitian dalam penelitian ini adalah sebanyak 7 orang

Data subyek Penelitian

\begin{tabular}{|c|c|c|c|}
\hline No & Nama & Kelas & Usia \\
\hline 1 & AN & XI IPA 2 & 16 \\
\hline 2 & WR & XI IPA 2 & 17 \\
\hline 3 & AT & XI IPA 2 & 17 \\
\hline 4 & RM & XI IPA 2 & 18 \\
\hline 5 & YW & XI IPA 2 & 17 \\
\hline 6 & SH & XI IPA 2 & 18 \\
\hline 7 & FF & XI IPA 2 & 18 \\
\hline
\end{tabular}

Berdasarkan hasil analisis data Profil Self Control siswa SMA Negeri 3 Wera menunjukan bahwa hampir sebagian besar siswa telah mampu mengendalikan perilakunya. Sebagaimana pendapat Rotter (Wiked, 2005) kendali diri merupakan keyakinan yang berasal dari individu untuk mengendalikan perilakunnya. Senada dengan Mischel (Pervin, 1984: 410) berpendapat kendali diri mengarah pada kekuatan individu untuk mengatur atau mengendalikan tindakannya menghadapi situasi terkendali. Di sisi lain, pada memperlihatkan rata rata siswa profil Self Control siswa peraspek memiliki kontrol keputusan (Decision 


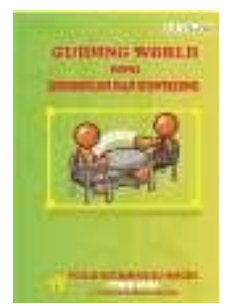

Control) yang kurang menggembirakan. Hal ini menunjukan bahwa masih banyak siswa yang belum mampu untuk memilih hasil atau suatu tindakan berdasarkan pada sesuatu yang diyakini atau disetujuinya. Siswa rata rata dalam mengambil keputusan masih dipengaruhi oleh orang lain, baik keluarga, teman maupun lingkungan sosial yang lain. Tampak bahwa program bimbingan klasikal efektif untuk meningkatkan total Self Control siswa. Terkait dengan aspek Self Control program bimbingan Klasikal efektif untuk meningkatkan seluruh aspek Self Control.

Dengan demikian, Program bimbingan Klasikal secara signifikan berpengaruh terhadap peningkatan skor total Self Control beserta aspek diberikan dukungan yang menandai dikhwatirkan kedepannya siswa tidak terampil dalam pengambilan keputusan . kendali diri dalam menentukan pilihan akan berfungsi baik dengan adanya suatu kesempatan, kebesan atau kemungkinan tindakan. Sebagaimana pendapat Averill (1973: 287) Decision Control merupakan kemampuan individu untuk memilih hasil atau suatu tindakan berdasarkan pada sesuatu yang diyakini atau disetujui. Pada aspek kontrol kognitif siswa rata - rata dalam kategori cukup terkendali. Hal ini memberi interprestasi bahwa siswa mampu mengelola informasi yang tidak diinginkan. Hal ini senada dengan aspek dan indikatornya, kecuali untuk aspek behavior control dengan indikator mengatur pelaksanaan. Mengatur, mengelola dan berprilaku sesuai dengan norma. Hal ini selaras dengan pendapat Logue (1995:24) orang yang mampu mengontrol diri adalah orang yang memiliki ciri ciri sebagai berikut: memegang teguh tugas yang berulang meskipun berhadapan dengan berbagai gangguan, mengubah prilakunya sendiri sesuai dengna norma yang ada : tidak menunjuk prilaku yang dipengaruhi oleh amarahamaah: dan bersikap toleransi terhadap stimulus yang berlawanan. Setiap individu penting mem;iliki sumber parameter estimate pengendalian diri yang baik seperti yang dijelaskan oleh Calhoun dan Acocella (Muharsih,2008) ada dua alasan diperlakukannya kontrol diri yaitu alasan sosial dan alasan personal. Dalam alasan sosial, individu tidak hidup sendiri melainkan dalam kelompok masyarakat. Individu harus mengontrol perilakunya agar tidak menganggu ketentraman sosial atau melanggar kenyamanan dan keamanan orang lain. Sedangkan alasan personal yaitu kontrol dibutuhkan individu untuk belajar mengenal kemampuan, kebaikan dan hal hal lain yang diinginkan dari kebudayaan. Averil (1973) menyatakan pengendalian diri sebagai salah satu potensi dasar yang dimilki oleh individu yang dapat dikembangkan dan digunakan individu selama proses proses dalam kehidpan, termasuk dalam menghadapi kondisi yang terdapat pada lingkungan tempat tinggalnya. Hurlock (2004:225) menjelaskan individu yang memiliki kontrol diri memiliki kesiapan diri untuk berprilaku sesuai dengan tuntutan norma, adat nilai nilai yang bersumber dari ajaran agama dan tuntutan lingkungan masyarakat dimana ia tinggal, emosinya tidak lagi meledak ledak dihadapan orang lain, melainkan menunggu saat dan tepat yang lebih tepat untuk mengungapkan emosinya dengan cara cara yang lebih diterima. Melalui layanan bimbingan klasikal siswa memperoleh informasi tentang nilai nilai yang berlaku dilingkungan keluarga, sekolah dan masyarakat yang disajikan dalam setiap materi baik itu melalui ceramah, tayangan video maupun diskusi kelas. Dengan demikian siswa dapat merubah prilakunya kearah yang lebih positif setelah mengikui kegiatan layanan tersebut. Menurut teori Pieget (dalam Yusuf, 2014) remaja berada pada tahap perkembangan intelektual atau kognitif operasional formal. Fakta ini sesuai dengan temuan temuan sebelumnya baik penelitian tentang Self Control maupun pada variabel bimbingan Klasikal. 


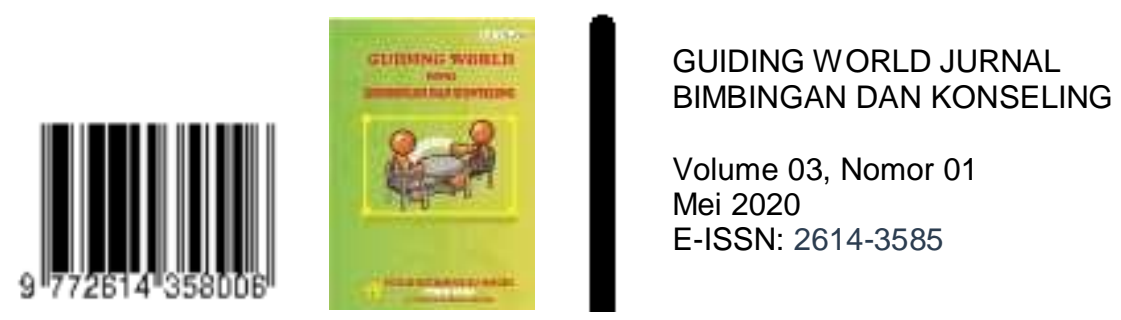

DOI: 1033627

Penelitian serupa tentang Self Control yang sama sama terbukti efektif diantaranya: Oktarini (2014) Efektifitas teknik Modeling untuk meningkatkan Self Control pada SMPN 2 Batu Sangkar, terbukti dengan 30 Teknik tersebut efektif. Penelitian Lestari (2006) tentang Konstribusi kendali diri terhadap kedisiplinan dengan judul Konstribusi kendali diri terhadap melalui belajar mengamati, individu secara kognitif menampilkan tingkah laku orang lain dan kemudian sering kali mengadopsi tingkah laku tersebut dalam dirinya sendiri.

\section{PENUTUP (12pt bold Styles Heading 1)}

Dari hasil pembahasan sebelumnya maka dapat diambil kesimpulan bahwa penerapan bimbingan klasikal dapat meningkatkan self control pada peserta didik, dalam penerapan bimbingan ini siswa dapat mengontrol atau megarahkan dirinya menjadi pribadi yang lebih baik dengan menerima kondisi dan situasi yang ada dilingkungannya dengan bersikap tidak menimbulkan perilaku dengan amarah dan dapat juga mengambil keputusan dengan masalah yang dihadapi oleh siswa itu sendiri. bimbingan klasikal ini diberikan kepada siswa oleh guru bimbingan dan konseling atau konselor sekolah kepada sejumlah siswa dalam satuan kelas yang dilaksanakan didalam kelas. Kebutuhan dan masalah yang bersifat umum, dihadapi oleh seluruh atau sebagian besar siswa, dan tidak selalu bersifat pribadi, dapat dibantu dengan secara klasikal atau kelompok besar. Disarankan agar guru pembimbing lebih memasyarakatkan layanan Bimbingan Konseling terutama Layanan Bimbingan Klasikal yang ada di Sekolah. Selain itu guru pembimbing harus berupaya lebih intensif menjelaskan manfaat dan kegunaan Layanan Bimbingan Klasikal agar siswa lebih memahami arti penting dari kegiatan Bimbingan Klasikal. Para siswa hendaknya dapat lebih memahami dan mengerti manfaat Layanan Bimbingan Klasikal agar dapat menambah wawasan siswa. Sekolah diharapkan dapat membuat Program agar para siswa mempunyai keinginan yang kuat untuk mengikuti Layanan Bimbingan Klasikal. Kepala Sekolah agar lebih memperhatikan dan dapat menunjang Program Layanan Bimbingan Klasikal di Sekolah.

\section{DAFTAR PUSTAKA (12pt bold Styles Heading 1)}

[1] Creswell, J.W. (2010). Alih bahasa, Achmad Fawaid. Research Design Pendekatan Kualitatif, Kuantitatif dan Mixed. Yogyakarta: Pustaka Pelajar.

[2] Desmina. (2013). Psikologi Perkembangan, Bandung: PT Remaja Rodakarya.

[3] Farozin, M. (2012). Pengembangan Model Bimbingan Klasikal untuk Meningkatkan Motivasi Belajar Siswa Sekolah Menengah Pertama. Jurnal Ilmiah Pendidikan, Cakrawala Pendidikan. 31 (1) .143-155.

[4] Ghufron, M. Nur dan Rini Risnawita. (2014). Teori-teori Psikologi, Yogyakarta: Ar-Ruzz Media.

[5] Hurlock, E.B. (2004). Alih Bahasa Istiwidayanti \&Soedjarwo. Psikologi Perkembangan Suatu Pendekatan Sepanjang Rentang Kehidupan. Jakarta: Erlangga.

[6] Kementerian Pendidikan Dan Kebudayaan Republik Indonesia. (2014). Modul Pelatihan Implementasi Kurikulum 2013, Jakrta: Badan Pengembangan Sumber Daya Manusia Pendidikan dan Kebudayaandan Penjaminan Mutu Pendidikan. 


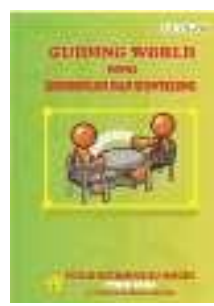

DOI: 1033627

Volume 03, Nomor 01

Mei 2020

E-ISSN: 2614-3585

[7] Marinus. (1997). Kontribusi Kendali Diri Terhadap Kedisiplinan Siswa di Sekolah. (Skripsi). Psikologi Pendidikan Universitas Pendidikan Indonesia, Bandung.

[8] Muharsih, L. (2008). Pengaruh Hubungan Antara Kontrol Diri Dengan Kecendrungan Perilaku Konsumtif Pada Remaja di Jakarta Pusat. Bandung: Skripsi Psikologi FIP UPI. Tidak diterbitkan

[9] Oktarini, I. (2014). Efektivitas Teknik Modeling untuk Peningkatan Pengendalian Diri Siswa. (Tesis). Sekolah Pascasarjana, Universitas Pendidikan Indonesia, Bandung.

[10] Prayitno \& Erman Amti. (2004). Dasar-dasar Bimbingan dan Konseling,Jakarta: Rineka Cipta.

[11] Paramitra, T. (2011). Kumpulan Lengkap Materi Bimbingan dan Konseling. Yogyakarta: Paramitra

[12] Permendikbud No 111 Tahun 2014.Tentang Bimbingan dan Konseling pada Pendidikan Dasar dan Pendidikan Menengah. Jakarta

Sugiyono,(2009). Metode Penelitian Pendidikan, Jakarta: Alfabeta.

[13] Surya. (2003). Program Bimbingan untuk Mengembangkan Kendali Diri Siswa. (Tesis). Sekolah Pascasarjana, Universitas Pendidikan Indonesia, Bandung 